\title{
Rethinking Debt: The Evolution of Private Credit Markets in Preindustrial France
}

\section{Elise M. Dermineur}

This article focuses on traditional private credit markets in eighteenth-century France through the examination of notarized loan deeds and to a lesser extent civil court records. It examines in particular how credit markets functioned and how they developed in the eighteenth century. It argues that traditional credit markets featured norms of solidarity, cooperation, and fairness, and allowed considerable flexibility and input from both creditors and debtors. But in the middle of the eighteenth century, this market experienced several major changes. Not only did the volume of exchange and the number of notarized credit contracts dramatically increase, engendering a standardization of contracts and a greater resort to external institutions, but a new group of investors modified the traditional norms and practices of exchange. This article concludes that the private credit market shifted from an institution in which input, negotiation, and flexibility prevailed to a more rigid institution in which rules and rigor applied.

\section{Introduction}

In 2005, the American housing bubble unexpectedly burst, causing deep disturbance to the real estate market in the United States. Thousands of American families ceased refinancing their household loans as their adjustable-rate mortgages got out of hand, causing a wave of foreclosures. A significant number of people lost their properties because the loans they had subscribed to were eventually subject to speculation in the stock market and to predatory lending, making them incredibly toxic. In the meantime, banks and insurance companies, which had not anticipated the bubble and the high number of failed payments, faced huge difficulties. Lehman Brothers Holdings in the United States, one of the most infamous investment banks, and one of the most important, could not avoid bankruptcy. Highly complex and sophisticated financial mechanisms, coupled with moral hazard, contributed to this situation and to the ensuing worldwide financial and social crisis in the following years.

In the meantime, the financial instability caused by this "subprime mortgage crisis" engendered the European sovereign debt crisis, one of its collateral effects. Several European countries not only encountered huge difficulties in repaying their public debts, but they were also unable to bail out their indebted national banks. Many had to call for the assistance of the European Central Bank and the International Monetary

I would like to acknowledge the generous support of the Riksbankens Jubileumsfond for this research. This article was written while in residence at the Swedish Collegium for Advanced Study in Uppsala, Sweden, and presented at a seminar there. I would like to thank all the seminar participants for their constructive comments and suggestions. 
Fund. Austerity programs were enforced to restore trust. New legislation was enacted to cut public spending and to facilitate the increase of fiscal revenues. And difficult negotiations with creditors opened. To this day, not a single European country had defaulted on its debt, despite great difficulties such as in Greece; there is a common assumption that a debt must be repaid as a matter of respect, fairness, and legality. In July 2015, during the Greek crisis, 74 percent of Finns were reported to think the "creditors should insist on the terms as they were initially agreed." Only 14 percent of Finns said that one "should reduce or renegotiate Greece's debt" (YouGov 2015). Sixty-four percent of Danes and 61 percent of Germans were to preach the same intransigence toward the Greeks. Protestants countries seemed to give reason to Max Weber (Weber 2008).

In the meantime, throughout the Western world, voices protested not only against the contemporary drift of capitalism, but also against the lack of morality in our financial system, calling for an overhaul and stronger ethics at the level of norms (Lazzarato 2012). Criticisms pointed to the dramatic vagaries of a system that appeared to have reached its limits, and that affected people who had never thought they would have anything to do with the abstruse world of the stock market. Social movements, such as the Occupy Movement, spread in many cities (Graeber 2013). These social protests also mutated into political movements such as Siriza in Greece, Podemos in Spain, or Movimento Cinque Stelle in Italy to name but a few. The emergence of these parties underlined the critical social and economic situation. Their leaders promised their electors they would find an alternative to austerity, and to a lesser extent an alternative to capitalism. Parallel to all of this, we have recently witnessed the development of crowd-funding platforms and peer-to-peer lending (or P2P) to skirt around traditional banking/lending circuits. Crowd funding increasingly appears a serious threat to bank loans (Les Echos 2015). In Greece, we have even witnessed the revival of bartering practices (Alderman 2015). People are looking for alternative circuits, not necessarily in a new fashion but they are, rather, looking for greater diversity.

Recently, David Graeber suggested a concept he labeled "everyday communism" in reference to the solidarity and norms of cooperation existing among traditional peasantry when it comes to the structure and organization of their communities, from the management of common lands to neighborly and daily mutual assistance (Graeber 2011). Laurence Fontaine, following the path set by E. P. Thompson, has also become one of the first scholars to refer to a moral economy for the early modern period, showing the mechanisms of charity and solidarity at work in traditional communities when it came to credit and highlighting its social dimension (Fontaine 2008; Scott 1977; Thompson 1971). But more importantly, Fontaine recognizes the vital importance of credit in early modern France, as she points to the emerging figure of the Homo creditus in the seventeenth century, highlighting the fundamental significance of credit to economic practice and social relations throughout Europe-and the mutually formative impact they had on each other-drawing attention to the multiplicity of circuits of credit at all levels of society. As Fontaine points out, microcredit is not a modern invention, and in premodern Europe it already helped people to subsist (Fontaine 2008: 156). But it was certainly a different system of microcredit and credit, based on interpersonal relations, reciprocity, solidarity, mutual trust, and flexibility. 
Graeber argues that a transition from "everyday communism"- presumably before capitalism-to "impersonal arithmetic" oriented toward profit making and the depersonification of exchange took place at some point in time, ending the reign of traditional exchange and replacing it with our modern practices (Graeber 2011: 14).

Debt, therefore, either private or public, had become a critical component of people's lives and one of the most important challenges for the future. How did financial exchange evolve in such an uncontrollable manner? Could the answer to current issues regarding credit and debt be found in the past? Can we look for the answers to these questions in the roots and origins of our current system, focusing especially on Europeans dwellers who lived and exchanged before the modern banking system was implemented? In eighteenth-century France, most financial transactions took place through inner circles and were sustained through strong norms of collaboration, fairness, and solidarity. In France, before the proliferation of banks, the volume of mortgage debt equaled 10 percent of GDP in 1807 (Hoffman et al. 2012: 40). Early modern credit markets remained for the most part local, hermetic, volatile, and highly embedded in social systems. But in the eighteenth century, practices of exchange evolved and changed, challenging traditional norms. These changes, in fact, molded the world of exchange we know today.

This article focuses on premodern credit transactions within traditional communities with special reference to changes pertaining to the eighteenth century, a key period of transition. The case studies are rural communities located in the south of Alsace, the seigneurie of Delle, and the seigneurie of Florimont. ${ }^{1}$ In this region, credit transactions took on a greater significance throughout the eighteenth century. Indeed, we can see not only an increase in the number of notarized transactions, but also an increase in the volume exchanged in the credit market. How can we explain this evolution? And what does this change mean? This change, I argue, can be explained through two quasisimultaneous phenomena. On the one hand, economic development, characterized by substantial growth resulting from improvements in a period of proto-industrialization and boosts in agricultural output required more capital and financial exchange for further investment. ${ }^{2}$ Purchasing land often required substantial financial means and had to be financed through credit as only a few could afford to pay outright. Simultaneously, macroeconomic factors - and to a lesser extent microeconomic factors - such as inflation, greater monetization of exchanges in rural areas, fragmentation of land, demographic pressure, and rise of consumerism, highlighted the need for investment, for cash, and/or for more financial transactions. These macroand microfactors drove the circulation of credit and money. On the other hand, we need to consider the increasing development of efficient credit tools correlated by the development of local institutions able to sustain an active and dynamic credit market. The institutions of the notary and of the local judge, in particular, were generally more solicited by dwellers and therefore increasingly turned into specialized institutions, experts in credit tools and debt management.

1. Archival records at the Archives départementales du Territoire de Belfort (ADTB hereafter). See esp. ADTB 2E4/155, 2E4/156, 2E4/157, 2E4/158, 2E4/159, 2E4/194, 2E4/222, 2E4/223, 2E4/245, 2E4/246, 2E4/257, 2E4/258, 2E4/279, and 2E4/280.

2. This is also argued by Philip Hoffman (2000). 
The first part of this article highlights the main characteristics of premodern credit markets and sheds light especially on the nature of contracts, the exchange networks, and the institutions sustaining this market. The second part examines the changes that occurred and modified the nature of the market throughout the eighteenth century.

\section{Credit Markets in Early Modern France: Characteristics, Norms, and Traditional Practices}

\section{Channels of Credit}

Marie Jeanne Prenez died in February 1782. The bailli of the seigneurie, a seigneurial officer, listed all her belongings in an inventory (ADTB 2E4/287). Her heirs would use it to divide the old woman's assets and belongings. Among Prenez's possessions were various contracts, cédules, and obligations. She had meticulously kept track of money owed to her. Most of these debts had been agreed on privately. It was common, indeed, to lend and borrow money to friends, neighbors, or family members, without the intercession of an external party such as the notary; to buy livestock or grains on tab; and then to inscribe in a register or on small notes the amount of money owed. It was not uncommon to contract credit through verbal agreement alone.

In early modern France, several channels of credit coexisted, on the one hand the institutionalized credit market, and on the other hand the more informal channels. Regarding informal credit exchanges, many small credit transactions between individuals still elude us, either because they were not archived or because they remained verbal agreements between parties (Pfister 1994: 1342). Creditor and borrower often knew each other and were bound either by family ties and/or by geographical proximity; they often exempted themselves thus from the burden of registering their transaction, which would have engendered in turn a greater cost (Dermineur 2015). They negotiated the terms of the agreement themselves, privately. We can track part of these transactions with the help of the probate inventories, such as that of Marie Jeanne Prenez. These arrangements were called "contrats sous seing privés." The amounts exchanged were also often small and did not necessarily require the official seal of the notary for the promise to be respected. These exchanges involved more flexibility in terms of negotiations regarding the terms of the contract, especially when it came to interest rates and the guarantees proposed. ${ }^{3}$ Many of these loans were deferred payments. This, in fact, can be explained by the lack of currency circulating in rural areas. In these contracts, guarantees could be brought to the deeds, but this does not appear to have been necessary. Despite the fact that avoiding notarial registration critically diminished the transaction cost, these contracts were not without risk, especially in case of nonrepayment. Indeed, in case of default, a lender lost his right of seniority on the debt and had very little chance of regaining his capital in court, as he could claim

3. It should be noted, however, that in early modern France an interest rate superior to 5 percent was legally considered usurious. The legal cap for notarized loans was 5 percent, except for the years 1766-70 when it was 4 percent. 
nothing on the debtor's estate. Traditional societies appreciated written contracts and peasants knew their importance; like Marie Jeanne Prenez, many of them kept records at home and copies of their transactions in a safe place.

The notary, however, was the official channel and institution for credit transactions (Hoffman et al. 2001b: 1994). In early modern Europe, notaries could be found in various regions, including Italy and Spain (Ago 1999; Nussdorfer 2009; Soldelvila 2014). In England, there were public notaries or scribes who might write down contracts (Cheney 1972). Throughout the early modern period, the French crown had attributed greater prerogatives to notaries. ${ }^{4}$ Since 1566 and the reform of justice, loans superior to 100 livres had to be registered before the notary against a fee or had to be written down between private parties (Isambert 1829: 203). This legal disposition underlines the effort being made by the state to rule out verbal agreements, which could hardly be claimed in court.

The notary wrote down a contract on demand against a fee (la grosse) and archived the contracts in registers to keep track of them-this being done with sloppiness. The notarial copies could be retrieved from the notary archives in case of conflict. In urban areas, notaries competed to attract clients (Hoffman et al. 2012, 1999). They used their expertise and the information available about potential creditors or debtors to match clients and overcome asymmetric information; increasingly becoming incontrovertible brokers, especially in cities where locating large capital was made more difficult because of anonymity, and the lack of strong bonds and trust. Presumably, competition between notaries in urban areas allowed less clients' input.

In rural areas, the notary remained a seigniorial agent at the disposal of his clients. Most often, one notary operated for an entire seigneurie. The seigneuries of Delle and Florimont each had their own notary or tabellion. One had his office in the town of Delle and the other had his in the village of Florimont. According to the needs of the seigneuries' inhabitants, both traveled throughout the countryside and stopped in certain villages to write up contracts for the peasants. The notary of the seigneurie of Florimont, for instance, stopped frequently at the mayor's house in Suarce or in Faverois-despite that all villages in the seigneurie were close to the main town. The office of notary often passed on from one generation to another. The rural notary's main task was simply to write down contracts. He could possibly act as a broker, but the social proximity, strong endogamy, and traditional norms prevented him interfering in peasant affairs. Peasants negotiated the terms of their contracts beforehand among themselves and concluded the agreement before the notary, bringing their own input to the deed. Despite the increase in the publication of manuals and the spread of such literature throughout the territory, a variety of notarial practices prevailed (Ferrière 1752).

It was not uncommon for rural dwellers to resort to both the notary and to the unofficial credit market throughout their lives. Jean Pierre Chappuis, a ploughman from the village of Croix, died in July 1779. The judge carefully noted the state of his

4. Royal notaries coexisted with seigneurial notaries, often called tabellion, but whose legal attributions were similar. 
financial situation, that is, his outstanding debts and his liabilities (ADTB 2E4/244). Fifteen different individuals owed him a total of 384 livres while he was indebted to nine different individuals to the tune of 75 livres. The majority of these transactions dealt with small amounts and had been agreed on privately. Moreover, Jean Pierre Chappuis had also resorted to the notary for a larger amount, and one can find him acting as a creditor, debtor, and guarantor, for many years in several transactions. Both the notarized circuits and the private circuit responded to different needs and different levels and norms of engagement and trust.

Other channels of credit, such as pawnbroking for instance, gravitated on the margins of the institutionalized credit market. Religious institutions and foundations could extend credit and recorded the transactions in their account books. Parish vestries were also prone to extend credit. They extended credit to a selected landed elite, offering often better and negotiable interest rates (Dermineur 2018). Finally, it is important to note that the notary and these alternate circuits of credit did not compete as they responded to different needs.

These circuits of exchange were perhaps not efficient by any modern definition, but they were well developed. As stated previously, in France, before the proliferation of banks, the stock of mortgage debt equaled 10 percent of GDP in 1807-despite the shock caused by the French Revolution and the ensuing war-proving the vitality of various local markets (Hoffman et al. 2012: 40).

\section{Variety of Contracts}

As the different channels of credit coexisted to answer various needs, we also find diversity in terms of contracts (Ago 1999: 196). For the purpose of this article, I will concentrate mainly on the institutional credit market and on notarial contracts. In early modern France, at least four major different types of notarized and official financial tools coexisted: obligation, rente perpétuelle, rente constituée, and rente viagère. The rente viagère (life annuity) was certainly the least common of the three contracts in the eighteenth century. The lender lent to the borrower a certain capital, usually a significant sum, which would be repaid annually with interest until the creditor's death. Following the death of the creditor(s), the payment stopped and the heirs could not claim anything from the borrower. But if the debtor died before his creditor, then his heirs had to continue the annual payments. This financial tool often served as a retirement pension. The rente perpétuelle (perpetual annuity) worked differently. A payment was made annually, including interest, until the principal was totally repaid. Usually the amount paid every year was fixed, giving the lender the assurance of a fixed annual income. The lender could not ask for the repayment of the capital, but the borrower had the possibility to repay the principal of his rente at once. The annuity was backed with specific pieces of land. The rente was transmissible to heirs in the case of the lender's death and if the capital had not been repaid by then. Parish vestries resorted to this type of contract for instance. The rente constituée (annuity) resembled the rente perpétuelle. It was attached to a specific piece of land. With a rente constituée, 
a lender extended money to a borrower until this latter decided to repay the capital in full. In the meantime, fixed interests - supposedly the revenues of the land-were paid every year. Ferrière argues that this rente constitutée resembled a "sale with the option to re-purchase" the land (Ferrière 1756: 483-84). Rente constituée functioned therefore somewhat as medieval British mortgages and was often assimilated and became confused with perpetual annuities (Briggs 2009; Servais 1994). Each of these three annuity contracts required collateral, usually in the form of land in rural areas.

The last credit instrument was probably the most common and popular one. Obligations, indeed, were notarized promissory notes, widely used by artisans and peasants because they were used for small amounts repayable in the short term. Hoffman et al. highlight the fact that "over the course of the eighteenth century, they (obligations) grew larger and more common, and by the nineteenth century, they came to dominate the credit market" (Hoffman et al. 2001a: 15). Their success can also be explained by the fact that it was possible to pass on, inherit, and exchange obligations. When Marie Elisabeth Jeantine got married in 1777, for example, her parents endowed her with an obligation amounting to 1000 livres (ADTB 2E4/392). In 1778, Marie Ursule Vautrin was also endowed by her mother with 12,000 livres invested in the market at a 5 percent interest rate (ADTB 2E4/276). In the seigneurie of Delle and Florimont, an obligation was the preferred credit instrument. Rente of any type rarely appeared in the notary's registers (Dermineur 2018).

In theory, obligation could not legally bear an interest rate (Hoffman 2001a: 15). In practice, however, the interest could be hidden in the capital or arranged on the side (Rosenthal 1993: 132). In the manors of Delle and Florimont, however, I have found that these contracts, just like rente, specified an interest rate; in the eighteenth century this was usually under or equal to the 5 percent legal rate..$^{5}$ It is safe to argue that in the eighteenth century, all types of contract could potentially bear interest (Hoffman et al. 1992: 296). I will return to this point shortly.

This rigid contract typology was nonetheless undermined in practice. In early modern France, similar credit instruments had different names and various characteristics. Obligation, incidentally, had a polymorphous and complex definition, and Jean Laurent Rosenthal recognizes that "even within the notarial system, the links between obligations and rentes remain unclear" (Rosenthal 1994: 291). The variety of notarial practices and flexibility in the terms of agreements explained this discrepancy (ibid.: 290). In my sample, for instance, the terminology obligation was widely used and did not take strictly into consideration the preceding definition. Peasants used the term obligation for all sorts of loans, the short term and long term, those with fixed duration and those with an undetermined duration, those for cash loans and those for deferred payments. Rentes and obligations, therefore, seem to have often been mixed and confused, allowing the users to have more input and flexibility regarding their financial exchange, thanks to the porosity of contracts' definitions.

5. One can explain the fact that obligation did bear an interest rate in this particular region because it was integrated into the French kingdom after the Thirty Years' War. The crown, then, decided not to touch to the "us et coutumes" of Alsace. This could have possibly applied for interest rates (see Rozet 1966: 7). 


\section{A Closer Look at the Sample: Obligations}

The sample includes two rural lordships or seigneuries located in the eastern part of the French kingdom, a few kilometers away from Basel. There, peasants constituted the core of the population. The seigneurie of Delle, owned by the Mazarin family since the seventeenth century, encompassed 18 villages in addition to the main town of Delle. In 1720, approximately 1,400 inhabitants lived there (in 1766, their number reached about 2,000). The town of Delle had about 300 to 400 inhabitants throughout the eighteenth century. The seigneurie of Florimont was smaller and counted 10 villages and about 800 inhabitants in 1720 (about 1,500 inhabitants in 1766) (ADTB $21 \mathrm{~J} 1,1720 ; 1766$ ). It belonged to a lesser noble family. In both seigneuries, all the villages were geographically close to one another. All the inhabitants could reach either Delle or Florimont in less than one day's walk. The level of endogamy was quite high.

In this area, the great majority of peasants owned their land (Boehler 1999: 45). Most of the land cultivated in both seigneuries was arable (more than 50 percent) while pasture — grazing and meadows - represented between 14 percent and 27 percent of the parcels of land. Peasants cultivated primarily oats, rye, barley, méteil (a mix of rye and wheat), potatoes, black wheat, and buckwheat. A three-year crop rotation was generally the norm. But contrary to the rest of Alsace, which was a fertile area, the quality of the soil in both seigneuries was poor (Varry 1995).

Husbandry, however, represented an essential complement to farming. For the most part peasants raised cattle, especially Montbéliarde cattle. Several livestock fairs were organized throughout the year in various towns, supporting a dynamic market in both seigneuries. In the south of the region, where the soil was chalky and hilly, peasants raised goats and sheep; wool was used for artisanal textile production.

As an extra, villagers cultivated a few flax and hemp fields, thanks to which they could produce small textile items intended for the local and the urban market. Peasants thus augmented their revenues through the production of small textile items. A survey of probate inventories in the eighteenth century reveals the ownership of a few weaving looms and raw material. It is rather difficult to estimate with precision the weight of these proto-industrial revenues for households. The merchants of Mulhouse, located about 50 kilometers away, might have provided outsourcing contracts for the peasants of Delle and Florimont. However, we have no evidence of this.

Millers, tanners, and other artisans were to be found in the two seigneuries; often they had some kind of agricultural activity on the side. If most of the inhabitants of the two manors by and large had occupations relating to agriculture and farming, there was a growing number of seigneurial officers (judges, notaries, lawyers, and clerks), especially in the second half of the eighteenth century. As we shall see, this category of the population had greater opportunities to save. Nonetheless, in this area, the "bourgeoisie enjoyed a modest wealth" (Rozet 1966: 6).

Obviously not everyone in these seigneuries had enough surpluses and savings available to invest in the credit market. The creditors belonged almost exclusively to the better-off strata of this heterogeneous rural population, while the debtors included 
TABLE 1. General overview of the credit market in the seigneuries of Delle and Florimont, 1730-90 (expressed in Livres tournoises)

\begin{tabular}{lcl}
\hline & Seigneurie of Delle & Seigneurie of Florimont \\
\hline Number of contracts & 1,463 & 622 \\
Volume & 442,473 & 304,534 \\
Mean loan & 302,5 & 489,6 \\
Median loan & 200 & 200 \\
\hline
\end{tabular}

Source: seigneurie of Delle: ADTB 2E4/155, 2E4/156, 2E4/157, 2E4/158, 2E4/159, 2E4/194, 2E4/222, 2E4/223, 2E4/244, 2E4/245, 2E4/246, 2E4/257, 2E4/258, 2E4/279, 2E4/280; Seigneurie of Florimont: 2E4/323, 2E4/324, 2E4/325, 2E4/366, 2E4/367, 2E4/368, 2E4/369, 2E4/370, 2E4/371, 2E4/372, 2E4/428, 2E4/429, and 2E4/430.

TABLE 2. Overview of the credit market in the seigneurie of Delle by periods, $1733-89$

\begin{tabular}{lllllll}
\hline & $1733-39$ & $1740-49$ & $1750-59$ & $1760-69$ & $1770-79$ & $1780-89$ \\
\hline Volume & & & & & & \\
Number of contracts & 131 & 179 & 194 & 207 & 280 & 472 \\
Mean & 180,6 & 250,3 & 241,8 & 236,6 & 358,2 & 376,9 \\
Median & 126 & 150 & 126,5 & 144 & 200 & 241 \\
& & & & & & \\
\hline
\end{tabular}

a wide range of individuals either looking for funds to make an investment or to makes ends meet.

In both seigneuries, peasants preferred to resort to obligations rather to any kind of annuity (rente) at the notary's office. In our sample, the majority of loan contract stipulates the names, place of residence, and sometimes the occupation of both the borrower(s) and the lender(s), the amount of money lent, the interest rate, the date of repayment, and the guarantees offered (collateral and assets pledged). Over the course of the eighteenth century (1733-90), I found 1,463 obligations recorded, amounting to a total of 442,473 livres for the entire period in the seigneurie of Delle. In the seigneurie of Florimont, I have found 622 contracts amounting to 304,534 livresa derisory amount compared to the 138 million livres annually exchanged in Paris (Hoffman et al. 1999: 76) (see tables 1 and 2). In traditional communities, the notarized credit market cohabitated with the informal credit market in which deferred payments, forms of bartering, and exchange of services were intermingled.

Notaries often omitted to specify the purpose of a loan (Brennan 2006: 177). Ferrière argues that a jurisprudence of 1664 made an obligation valid despite the fact that its motivation was not stated (Ferrière 1771: 250). Therefore, not only is it difficult to have a clear estimate on the purpose of the loan, but it is also challenging to assess whether a loan was a deferred payment for a commodity or an actual loan in cash 


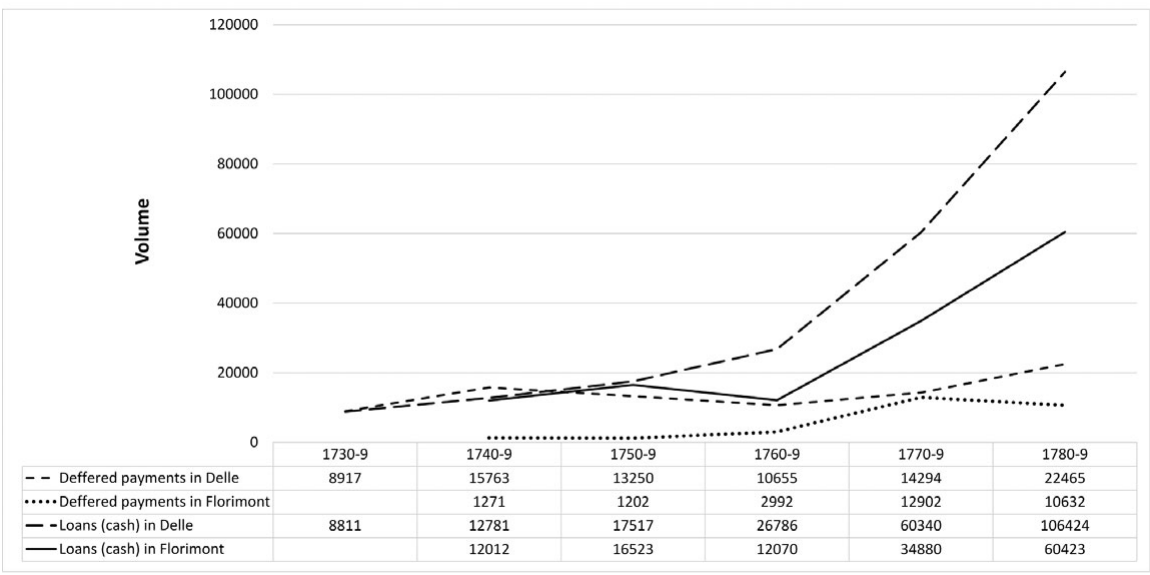

FIGURE 1. Purpose of loans in the seigneuries of Delle and Florimont according to the volume exchanged (1730-89)

(see figure 1). ${ }^{6}$ Running an estimate with the data available, we note nonetheless that the volume of exchange for deferred payments began to decrease in the middle of the eighteenth century, while loans in cash rose impressively, which could indicate a greater penetration of money in rural areas (see figure 1).

Creditors and borrowers agreed on short-term loans. Obligations were by definition short-term agreements. In the seigneurie of Delle, most of the contracts stipulated a deadline for repayment of either one year ( 45 percent) or three years ( 28 percent). In the seigneurie of Florimont, however, the length varied between one year (20 percent), three years (15.4 percent), and "on demand" (43 percent). The case of on-demand repayment ("à première requisition") is interesting. An on-demand repayment meant that the creditor could ask for the repayment of his capital when he pleased-with preagreed notice. As Chris Briggs argues, "[L]ending without a fixed repayment date could also engender patron-client relations" (Briggs 2009: 69). It is not exactly clear why in some areas dwellers and notaries favored a certain length over others.

But despite the fact that most deeds specified a short-term deadline, in practice however, it took longer for borrowers to repay-therefore the initial length specified in the contract mattered very little. As a result, some loans were renewed either informally or formally. ${ }^{7}$ Some of these loans were not renewed before the notary, as this would have meant an additional transaction cost (Waddilove 2014). But most were simply "rolled over" if the interest was paid. Some of these loans could roll over to several generations, resulting in much indebtedness.

6. Under the category loans (cash), we can find loans that were made in cash but also loans for which it cannot be certain were in cash. Those only mentioned a "just and legal loan of money" ("juste et légal prêt d'argent"). In the absence of other information, I assume the money was delivered in cash.

7. The rise of debt litigations in the eighteenth century indicates the difficulty borrowers had in repaying their debt on time. 
In April 1752, the priest of the village of Courtelvant, Francois Tissot, loaned 48 livres in cash to the widow Marguerite Soudain. She was supposed to repay the capital within one year. The loan was interest free, but 10 perches of meadow and a piece of arable land had been mortgaged, presumably to pay the interest in kind. The widow died in 1760 without repaying the capital to the priest (ADTB 081 E dépôt GG 1-6). It is likely that the priest regularly received interest in kind from the land mortgaged. Soudain's sons Jean Jacques and Joseph Chellet became liable for their share when their mother died. In 1769, they paid 78 livres to Tissot's heir ${ }^{8}$ — his niece, Marie Thérèse Tissot - in addition to another unspecified payment made a day later (ADTB 028 E dépôt GG1-3 and ADTB, 2E4/409).

On May 7, 1747, Bernard Liron, a peasant living in the village of Florimont, asked his seigneur for a loan of 100 livres (ADTB 2E4/409). We cannot know its purpose, but the sum was delivered in real money, in "escus de six livres." Gaspard de Barbaudthe seigneur of Florimont-and Liron agreed that the loan would be repaid within a year at a 5 percent interest rate and that Liron would pledge all his belongings, including a newly built house, to guarantee the transaction. Liron died in March 1748 before he had repaid his debts. Liron's heirs, liable for their share of the debt, paid the interest over several years; we can find evidence of this here and there. After 1779, 31 years after the initial agreement took place, it seems that the capital had finally been fully repaid. The lord had lent 100 livres and received back more than 238 livres at least.

Loans usually mentioned collateral in the form of land, livestock, real estate property such as houses, or simply in the form of all the borrower's goods ("tous ses biens meubles et immeubles"). A cosigner could also be added to the deed. In theory, women could not act as security, but they can be found in this position throughout the eighteenth century.

The majority of the loans specified an interest rate of 5 percent (or 4 percent between 1766 and 1770), which corresponded to the legal ceiling. In early modern Europe, setting the maximum legal interest rate for loan contracts was a royal prerogative. The maximum interest rate had decreased throughout the period. In early modern England, the Usury Act of 1571 made charging for interest legal with the acts of 1571 and 1598 , setting a rate of 10 percent, reduced in 1624 to 8 percent, 6 percent in 1650 , and finally set at 5 percent in 1713. In Catalonia and Aragon, the maximum interest was set to 5 percent in the seventeenth century and was subsequently dropped to 3 percent in the eighteenth century. In France, the edict of 1634 set the legal rate to 5.555 percent, reduced in 1665 to 5 percent for the entire kingdom; a rate that would remain more or less unaltered until 1914 (Hoffman et al. 2001a: 35; Isambert 1829: 70-71).

In theory, it was illegal to ask for an interest superior to 5 percent. Up to 5 percent, an interest rate was not considered usurious because it was a fair compensation for what was lost, that is, the use of the capital by someone else (the Latin verb intereo means "to be lost," interest was therefore not profit but loss) (Homer 1963: 71). 
In practice, however, interest could be disguised in the terms of agreement and the loan overpriced (Shaw 2013: 243). This practice was not uncommon, and it could have been perceived as usury. Indeed, the combination of a deadline and an interest fee constituted the crime of usury. In theory, only an annuity contract allowed the lender to ask for interest because the annuity had no fixed limit in time regarding the repayment of the capital. It was understood that charging for "time" was a godly prerogative only. But negotiating an interest fee and disguising them in the terms of the agreement seemed to constitute an important feature of traditional financial exchange, highlighting a critical level of user input. Overall, usury and interest ceilings did not seem to have a negative effect on the dynamism of credit activities.

Only a few loans were interest free, or at least in appearance. In June 1740, Alexis Gladieu sold two steers to Jacques Monnier and his wife Jeanne Feriez for 87 livres. The couple, who could not pay outright, agreed to pay Gladieu within a year without interest, pledging two specific plots of land. Gladieu would make use of the plots until full payment for the steer was made. Craig Muldrew argues that, in the seventeenth century, "because lending was so reciprocal, interest was not charged on sales credit to account for any risk as opposed to money lending, or lending on bond, where interest was standard by the seventeenth century" (Muldrew 1998: 173). But it seems that even for deferred payments, peasants did find ways to get compensation for the inconvenience of not being paid directly and passing on merchandise or property.

Credit exchange took place in local markets between individuals of prior acquaintance largely through concentric social circles as individuals sought credit first from their relatives, friends, neighbors, and other economic partners before turning to more distant potential lenders (Fontaine 2008). The more loose the ties between parties, the less trust between them is observed (see figure 2). The credit market in the seigneuries of Delle and Florimont worked in an almost hermetic sphere, that is, most of the agents were inhabitants of the seigneurie. Capital from beyond the seigneurie's borders remained therefore extremely marginal. We do not find external agents such as merchants for instance. ${ }^{9}$ We must also note that 30 percent of the loans were made between people living in the same village in the seigneurie of Delle (40 percent in Florimont), tied by strong norms of cooperation, emotional norms, and kin relationships. It was almost exclusively a peasant market.

\section{When Things Went Wrong: Claiming Repayment}

Strong norms of solidarity within the community and a flexibility of legal norms within the traditional local credit market did not prevent quarrels between parties. Conflicts regarding the repayment of the capital, repayment of the interest, or simply regarding meeting the deadline did occur. Parties could resort to extrajudicial means of negotiation and consensus and settle conflicts among themselves. We can find

9. The notarial credit markets of Delle and Florimont were composed exclusively of agents living in the seigneurie. A few of them were "merchants," e.g., livestock dealers. They did not, however, follow any specific merchant regulations related to credit activities. On this point see Kadens (2015). 


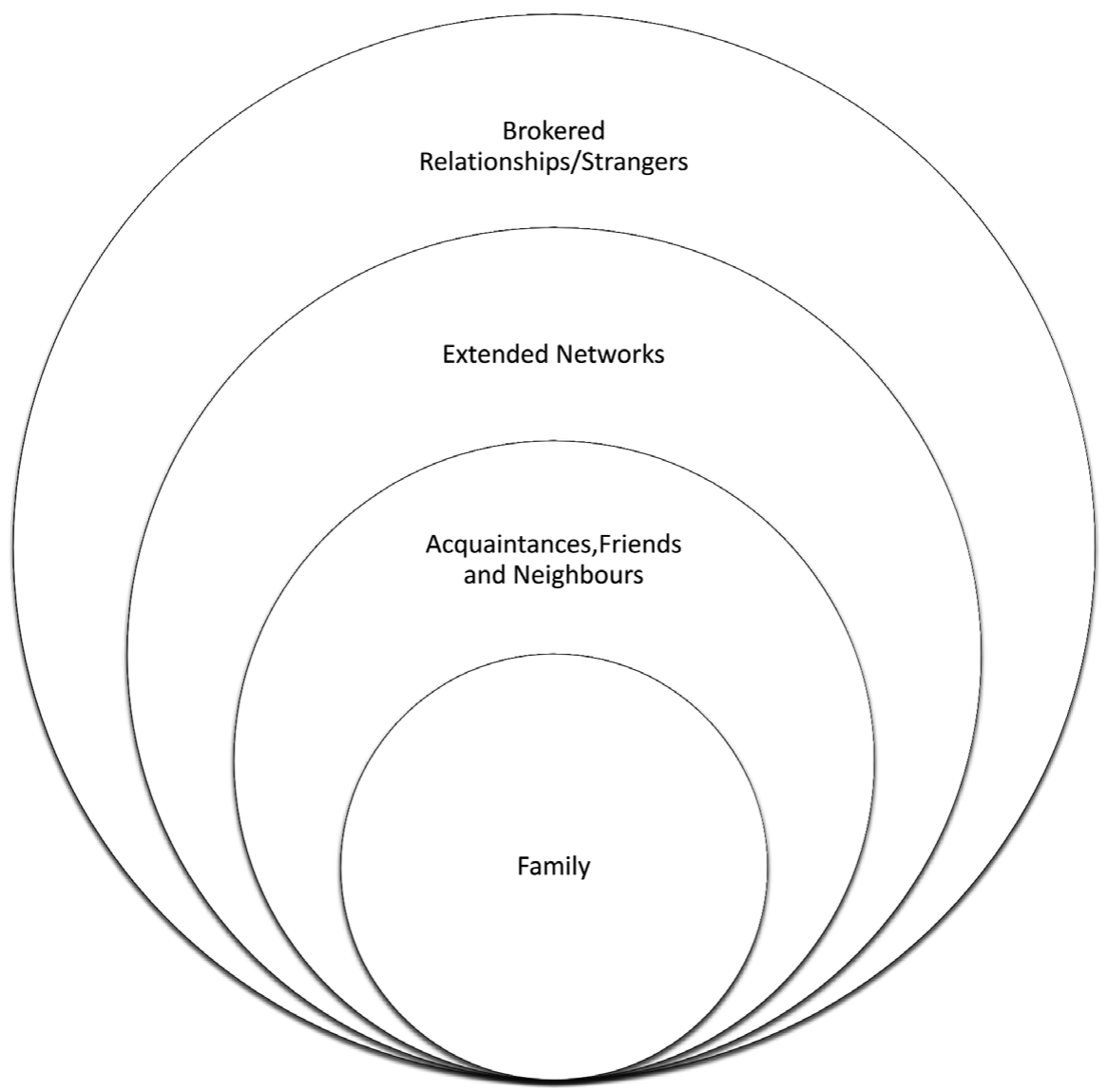

FIGURE 2. Representation of Concentric Networks of Credit in Early Modern France

evidence of this here and there in the archives, but it is extremely difficult to assess precisely the proportion of such negotiations. In case of default, the lender could also resort to the local court to claim the outstanding debt; the local judge was either a royal officer or a seigneurial officer. In early modern France, justice was indeed a royal prerogative, with the king as the only "owner" of justice in his kingdom. However, a multitude of local lords had lawfully earned the right to maintain a tribunal and nominate local judges in the Middle Ages as it was impossible for the king to deal out justice in person (Dermineur 2011b). ${ }^{10}$ Both the local civil court and also the criminal court handled matters relating to debt.

In the region under study here, a local civil judge sat in Delle and Florimont, in both instances the judge was a seigniorial agent. The audiences were public and often

10. In the sample studied, there was one seigneurial judge, rudimentarily trained in law. 
dealt with a wide range of issues. In the second part of the eighteenth century, these local courts increasingly came to deal with debt procedures, as we shall see (ibid.).

In cases of dispute, the local judge summoned the parties to appear in court, assessed the validity of the contract and requested the terms of agreement to be enforced. If the debtor fell short of resources and could not meet the terms of payment, the judge ordered foreclosure and auction of the assets. We find evidence of such auctions in the land sales records. It is important to note that imprisonment on grounds of debts decreased sharply throughout the early modern period (Claustre 2006). The judicial process, however, often proved to be quite long and costly in the case of foreclosure. The judge could nominate an external party-a mediator-to help the parties reach consensus and avoid foreclosure. In fact, many lawsuits stopped after the first hearing at court; parties preferred to resume talks and negotiations privately. Creditors rarely foreclosed, and debtors did not have to sell or cede their mortgaged land (Brennan 2006: 176). Most often, deadline repayments were extended; a strategy allowing both parties to find themselves satisfied, without losing too much from the initial terms. If there were several creditors asking for repayment, the judge ordered the formation of a "union des créanciers"- a creditors' group (Coquery and Praquin 2008). This group of creditors met and negotiated together the terms of the bailout, deciding new terms and new deadlines if possible. As Natacha Coquery notes, "[A]rrangement often meant bargaining" (Coquery and Praquin 2008: 68). If consensus was not possible, the creditors lined up in a queue before the debtor's assets being seized. As asymmetric information prevailed, it was almost impossible for a creditor to estimate the number of other creditors competing for repayment.

There is an increase in the number of litigations pertaining to the repayment of debts throughout the period. This encompassed a wide diversity of cases, being either notarized debts or informal transactions. For instance, in April 1780, Jean Nicolas Donzé asked for the payment of grain he sold and delivered to Jean Maurice Bergé. The grain had been delivered and it was understood that Bergé would pay for it later. The parties had agreed and contracted privately. As he could not meet the deadline, Donzé preferred to go to court to claim the repayment and therefore forced the debtor to recognize his debt. Complications could also arise in the case of inherited debt. In September 1780, Francois Rapinez asked the judge to enforce repayment of money owed to him by the heirs of one of his creditors. The heirs, Catherine and Marie Jeanne Prenat contested the amount due and conflict ensued between parties. In the case of succession, parties found themselves before the court quite often. In December 1781, Toussaint Dauphin asked for the repayment of 54 livres owed to him by Henri Joseph Biche. The judge looked at the "contrat sous seing privé" between the parties and ruled in favor of the creditor. In fact, the judge in the majority of cases ruled in favor of creditors. As a result, and perhaps to gain time and/or spare themselves the public shaming, debtors did not often present themselves in court (Dermineur 2011a).

Traditional local credit markets, therefore, functioned on a strong basis of norms of cooperation, solidarity, fairness, and highly flexible legal norms. Both creditors and debtors had a considerable input regarding the terms of their agreement before contracting and retained flexibility afterward, especially in relation to deadline repay- 
TABLE 3. Overview of the credit market in the seigneurie of Florimont, 1740-89

\begin{tabular}{lccccl}
\hline & $1740-49$ & $1750-59$ & $1760-69$ & $1770-79$ & $1780-89$ \\
\hline Volume & 15,040 & 25,983 & 26,749 & 92,632 & 144,130 \\
Number of contracts & 55 & 60 & 71 & 198 & 238 \\
Mean & 274 & 432,5 & 376,7 & 467,8 & 605,5 \\
Median & 130 & 125 & 200 & 205,5 & 292 \\
& & & & & \\
\hline
\end{tabular}

ment and payment of interest; this elasticity, however, did not prevent rural dwellers entering conflict. But in the second half of the eighteenth century, this pattern was altered; these traditional norms were challenged.

\section{Evolution of Credit Exchange in the Eighteenth Century}

\section{Dynamism of Credit Activities in the Eighteenth Century}

One of the main features of local credit markets in the Old Regime resided in their dynamism. In the eighteenth century, credit activities intensified throughout early modern Europe. This is true for major cities like Paris but also for rural areas (Hoffman et al. 1999: 76). In our sample, we observe a major increase of credit activities in both seigneuries. Not only did the number of notarized transactions increase-especially after 1770 - but the volume of exchange also intensified (see tables 2 and 3). In both seigneuries, the median transaction also increased throughout the eighteenth century.

The dynamism of notarized credit activities had an impact on traditional credit practices as we shall see. It is obviously difficult to measure how it affected the informal credit market. A rapid survey of probates shows the prevalence of both informal circles (mostly for small amounts) and notarized contracts throughout the century.

How can we explain these changes and this evolution? At the local level, it is likely that a simultaneous combination of growing proto-industrialization, dynamic commercial exchange, demographic pressure, and inflation occurred in this specific region, especially after 1770 (Dermineur 2011a: 112). But the same trend in the intensification of credit activities has also been observed in Paris around 1760 (Hoffman et al. 2001a: 131). Local and national inflation, for instance, especially the price of wheat, followed the same pattern of increase (Baulant 1968). It is important to note that dynamism in the service-oriented sector and the development of proto-industry stimulated employment and offered workers, including women, greater opportunities not only in terms of labor but also, and more importantly, in terms of income, allowing a greater circulation of liquid assets. This trend has been observed in various regions. In rural areas, proto-industry not only helped to cope with bad harvests or heavy taxation for instance, but it also provided greater income for households, bringing energy to the 
TABLE 4. Women borrowing money in the seigneurie of Delle, 1733-89

\begin{tabular}{|c|c|c|c|c|c|c|c|c|c|c|c|c|}
\hline & \multicolumn{2}{|c|}{$1733-39$} & \multicolumn{2}{|c|}{$1740-49$} & \multicolumn{2}{|c|}{$1750-59$} & \multicolumn{2}{|c|}{$1760-69$} & \multicolumn{2}{|c|}{$1770-79$} & \multicolumn{2}{|c|}{$1780-89$} \\
\hline & $N$ & $V$ & $N$ & $V$ & $N$ & $V$ & $N$ & $V$ & $N$ & $V$ & $N$ & $V$ \\
\hline Unmarried women & 0 & 0 & 2 & 846 & 3 & 572 & 4 & 353 & 5 & 1110 & 6 & 1075 \\
\hline Married couples & 24 & 6875 & 42 & 14814 & 65 & 15186 & 89 & 19442 & 125 & 42727 & 222 & 84363 \\
\hline Widows & 10 & 1570 & 8 & 1102 & 10 & 3611 & 4 & 2934 & 20 & 14198 & 32 & 10815 \\
\hline Groups & 0 & 0 & 1 & 200 & 1 & 200 & 3 & 1140 & 5 & 1710 & 3 & 1812 \\
\hline Men & 97 & 15222 & 126 & 27850 & 115 & 27340 & 107 & 25103 & 125 & 40542 & 209 & 79861 \\
\hline Total & 131 & 23667 & 179 & 44812 & 194 & 46909 & 207 & 48972 & 280 & 100287 & 472 & 177926 \\
\hline
\end{tabular}

$\mathrm{N}=$ number, $\mathrm{V}=$ volume

local market and household consumption (Vardi 1993). A close analysis of probates across the period suggests indeed that rural dwellers purchased new types of goods and adopted new consumer behavior (Sarti 2002). Meanwhile, demographic figures underline a stable increase in the French population throughout the eighteenth century. However, national inflation played a critical role in the rise of prices throughout the eighteenth century, especially after 1720 . Both demographic increase and inflation do not suffice to explain the dynamism of private credit markets throughout the kingdom (Hoffman et al. 2001a: 128). Additionally, national shocks did not seem to have an impact on credit activities in both seigneuries, contrary to other markets (Rosenthal 1994: 294). In 1770, the crown defaulted on its short-term debt, triggering a series of financial crisis throughout the kingdom. But the seigneurie of Delle and Florimont, sealed against external participation, do not seem to have been affected by the crisis. Other structural and factors needs to be taken into consideration, as we shall see in the following sections.

\section{Increase in Female Participation}

Not only did the number and the volume of financial transactions increase after 1770 but the number of women involved in credit exchange also followed the same trend. Women increasingly borrowed and lent after 1760 (Dermineur 2014a, 2014b, 2016). The most striking aspect of this is the participation of married women as borrowers. In the seigneurie of Delle, women (regardless of their marital status) signed 684 loans (46.75 percent) and borrowed a total of 226,655 livres (51.2 percent of the total exchanged), while in the seigneurie of Florimont, female borrowers signed 353 deeds (56.7 percent) for 128,055 livres borrowed (42 percent of the total). In other words, women, in both seigneuries, borrowed almost half of the capital available. But if we consider these figures more closely, it appears that marital status played a key role in the allocation of funds (see tables 4 and 5). Unmarried women and widows represented the minority of the borrowers while the proportion of married couples in need of 
TABLE 5. Women borrowing money in the seigneurie of Florimont, 1740-89

\begin{tabular}{|c|c|c|c|c|c|c|c|c|c|c|}
\hline & \multicolumn{2}{|c|}{$1740-49$} & \multicolumn{2}{|c|}{$1750-59$} & \multicolumn{2}{|c|}{$1760-69$} & \multicolumn{2}{|c|}{$1770-79$} & \multicolumn{2}{|c|}{$1780-89$} \\
\hline & $N$ & $V$ & $N$ & $V$ & $N$ & $V$ & $N$ & $V$ & $N$ & $V$ \\
\hline Widows & 4 & 631 & 6 & 1,006 & 5 & 660 & 10 & 4,210 & 15 & 4,058 \\
\hline Groups & 2 & 200 & 2 & 2,209 & 1 & 323 & 2 & 300 & 4 & 1,505 \\
\hline Men & 40 & 11,711 & 37 & 20,599 & 42 & 20,770 & 56 & 53,426 & 94 & 69,973 \\
\hline Total & 55 & 15,040 & 60 & 25,983 & 71 & 26,749 & 198 & 92,632 & 238 & 144,130 \\
\hline
\end{tabular}

Source: seigneurie of Delle: ADTB 2E4/155, 2E4/156, 2E4/157, 2E4/158, 2E4/159, 2E4/194, 2E4/222, 2E4/223, $2 \mathrm{E} 4 / 244,2 \mathrm{E} 4 / 245,2 \mathrm{E} 4 / 246,2 \mathrm{E} 4 / 257,2 \mathrm{E} 4 / 258,2 \mathrm{E} 4 / 279,2 \mathrm{E} 4 / 280$; Seigneurie of Florimont: 2E4/323, 2E4/324, 2E4/325, 2E4/366, 2E4/367, 2E4/368, 2E4/369, 2E4/370, 2E4/371, 2E4/372, 2E4/428, 2E4/429, and 2E4/430. Note: $\mathrm{N}=$ number; $\mathrm{V}=$ volume.

credit increased throughout the century to reach important proportions in the last decade.

We may ask why married couples signing deeds at the notary's office throughout the eighteenth century were more and more numerous, especially after 1760 tables 4 and 5. Married couples not only sought more funds, but their numbers gradually increased in the credit market. This phenomenon can be observed in both seigneuries and the shift seems to have occurred at about the same time in both. In Delle, 567 married couples sought credit ( 38.75 percent) for a total of 183,407 livres (41.44 percent) throughout the period. While they represented only 29.04 percent of the borrowers in 1733-39, they were 47.41 percent in the last decade of the eighteenth century. In the seigneurie of Florimont, the same pattern applied. A total of 291 married couples (46.78 percent) signed loans at the notary for 111,008 livres (36.45 percent), their proportion increasing in number throughout the eighteenth century; while only 15.6 percent sought credit in the first period of our sample, 47.4 percent did so in the last decade. In both seigneuries, the increase of married debtors was constant but seems to have taken off in the 1760 s as figure 3 shows.

The main explanation for this change may reside in the fact that peasants had increasingly mortgaged a good deal of their land to secure their transactions in the seventeenth and beginning of the eighteenth century. Some pieces of land were mortgaged for long periods and often presumably served to pay interest in kind. Creditors had no control and no information about what land had been mortgaged, or not, as no record was established, even if the intercession of notaries could be helpful to inform them in this matter (Hoffman et al. 1994b). In the meantime, the numbers of default proceedings at court increased after 1770s (Dermineur 2011b). In this context of lack of information and a deficit in trust, creditors were eager to secure their investments through new guarantees.

Looking closely at guarantees, we note that in the 1730s and 1740s, most of the loans contained specific mortgage guarantees, usually in the form of a specific piece of 


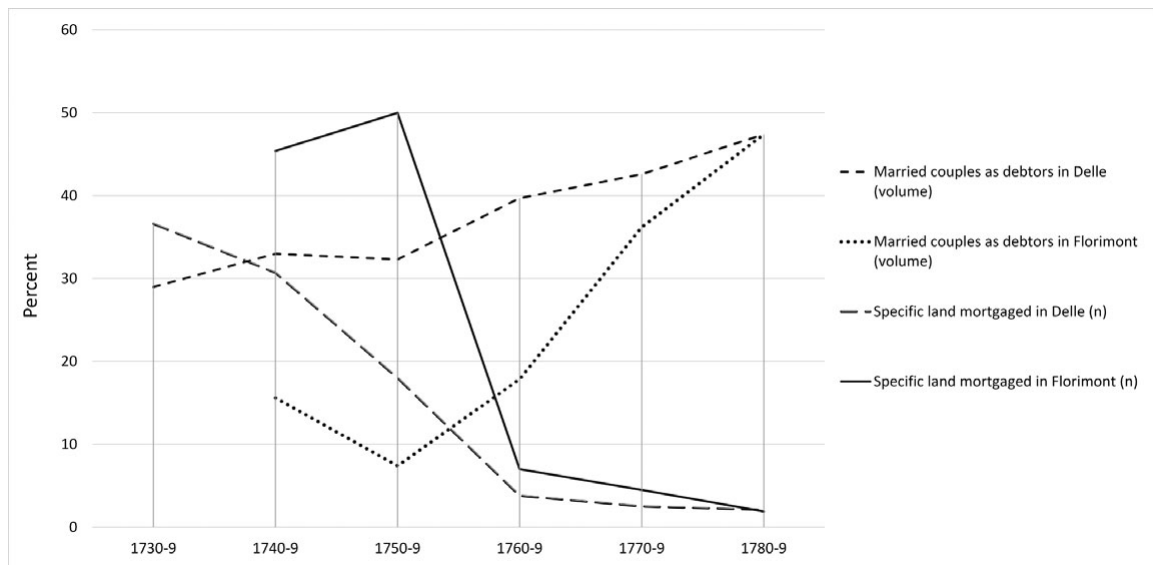

FIGURE 3. Volume of money borrowed by married couples in the seigneurie of Delle and Florimont correlated with guarantees, 1733-89

TABLE 6. The evolution of guarantees over time, 1730-89

\begin{tabular}{|c|c|c|c|c|c|c|c|c|c|c|c|c|}
\hline & \multicolumn{4}{|c|}{ Cosigners } & \multicolumn{4}{|c|}{$\begin{array}{l}\text { Specific piece(s) } \\
\text { of land mortgaged }\end{array}$} & \multicolumn{4}{|c|}{$\begin{array}{l}\text { Specific piece }(s) \text { of land } \\
\text { mortgaged and guarantor }\end{array}$} \\
\hline & $N(D)$ & $\%(D)$ & $N(F)$ & $\%(F)$ & $N(D)$ & $\%(D)$ & $N(F)$ & $\%(F)$ & $N(D)$ & $\%(D)$ & $N(F)$ & $\%(F)$ \\
\hline $1730-39$ & 20 & 15.3 & N/A & N/A & 48 & 36.6 & N/A & N/A & 13 & 9.9 & N/A & N/A \\
\hline $1740-49$ & 42 & 23.5 & 1 & 0.5 & 55 & 30.7 & 25 & 45 & 25 & 13.9 & 3 & 5.4 \\
\hline $1750-59$ & 54 & 27.8 & 1 & 0.6 & 35 & 18 & 30 & 50 & 20 & 10.3 & 9 & 15 \\
\hline $1760-69$ & 86 & 41.5 & 5 & 3.5 & 8 & 3.9 & 5 & 7 & 2 & 0.9 & 2 & 2.8 \\
\hline $1770-79$ & 112 & 40 & 28 & 14.1 & 7 & 2.5 & 9 & 4.5 & 5 & 1.8 & 3 & 1.5 \\
\hline 1780-89 & 247 & 52.3 & 62 & 26 & 10 & 2.1 & 5 & 2 & 4 & 0.8 & 2 & 0.8 \\
\hline
\end{tabular}

D: Seigneurie of Delle; F: Seigneurie of Florimont

land, while at the end of the period the notary laconically inscribed on most contracts that the debtor(s) would mortgage "tout ses biens tant meubles qu'immeubles," a general claim on the borrower's assets. This tendency can be seen in both seigneurie, although it appears to be more pronounced in the seigneurie of Delle (see table 6). Third-party underwriters were gradually associated to the deed while women's lineage property became even more interesting to creditors, especially presumably because of their dowries. Indeed, husbands and wives borrowed together and therefore offered greater guarantees to their creditors. Mortgaged lands no longer represented enough of a guarantee, and married women's property (mostly unmortgaged plots of land and cash either inherited or owned through dowries) now represented an additional and better guarantee in the eyes of creditors. Finally, I must underline that creditors could seek repayment by turning to the widow for her share of the debt in the case of 
her husband's death, rather than to multiple heirs - the widow would be accountable for 50 percent of the debt in the case of a joint loan (Dermineur 2016). After 1760, peasants not only had to add their wives and their wives' lineage property to the deed, but also had to find, in most cases, a third-party underwriter to reassure lenders. This crisis of trust was directly linked to the emergence of a new type of creditor (Dermineur 2015).

\section{Appearance of New Investors}

There is a major change in the profile of the socioprofessional activities of creditors in the second half of the eighteenth century. ${ }^{11}$ In the seigneurie of Delle, from the $1730 \mathrm{~s}$ to the 1760 s, the data show that peasants represented 65 percent of the total creditors, while in the last decade of the Old Regime they only represented 35 percent. $^{12}$ This major change can be explained by the involvement of a new type of creditor, from the liberal professions (lawyers, clerks, mostly service-oriented workers) and seigneurial agents (judges, notaries, clerks, etc). In the 1730s, these latter lent 10.7 percent of the volume exchanged (48.16 percent for the peasants), while in the last decade of the Old Regime they lent 30 percent of the total volume (31 percent for the peasants).

In contrast, in the seigneurie of Florimont, where the main town did not expand and where opportunities in service and administration remained marginal, we see a different trend. The number of liberal professionals and seigneurial agents who lent money did rise a little bit after 1760 but their number remained negligible; even if their capacity to lend was higher than some other groups (17.2 percent of the volume exchanged for the entire period), they probably did have less impact on market practices than in Delle. By contrast, in this seigneurie we can see a better and more equal distribution of socioprofessional categories among the better-off strata of the population where the nobility, for instance, played an important role (15.3 percent of the volume exchanged for the entire period with more investment on their part after 1760). Fluctuations across time do not show much change. Peasants still extended most of the credit in this seigneurie. However, the allocation of credit remained in the hands of a happy few; even if the number of contracts steadily rose after 1760 , the number of creditors remained limited (30 different creditors in 1740-49 for 55 contracts compared to 69 single creditors for 238 contracts in 1780-89).

In Delle and Florimont, this local bourgeoisie seemed genuinely interested in the possible profit to be made by extending credit to borrowers, thanks to a network of clients and an interesting rate of 5 percent. The seigneurial agents, officers, and local nobles not only had sufficient capital and savings to invest, but also had the possibility

11. The notaries were inconsistent and somehow sloppy in writing down the professions of the creditors, therefore the data must be considered as an estimation.

12. Loans registered by the notary rarely specified the occupations of debtors, largely because most of them were peasants. Contrary to this, the rate of professions known for creditors was much higher, around 60 percent. Rosenthal has also observed that most of the borrowers in Nuits Saint Georges were farmers, while the creditors were merchants and notaries (Rosenthal 1994: 292-93). 
of leaving it in the credit market for several years, thus enjoying the interest fees they could earn each year. Many used the credit market as a long-term investment instrument. After 1760, it seems that the credit market constituted a better investment place, with greater attraction than the land market where moral hazard and uncertainty regarding harvests, land management, and weather, for instance, remained high. More importantly, credit market investment allowed creditors to receive, in theory, regular payments made in cash. The example of the seven members of the Taiclet family, occupying seigneurial offices, is interesting in this regard. Throughout the eighteenth century, this family from Delle contributed to loaning 6.71 percent of the total volume of the exchange in the credit market. ${ }^{13}$ They used their networks and their information to make profitable investments and manage their portfolio.

The emergence of a new group of investors from the better off strata of the population had an impact on market practices. Indeed, as outsiders of the peasants' socioprofessional group, these new investors were less inclined to trust debtors and consequently required more guarantees (Dermineur 2015). As we have seen, the guarantees proposed in the deeds evolved throughout the eighteenth century. Increasingly, less and less specific pieces of land were mortgaged. This feature also must be correlated with the emergence of a new group of investors. These latter were probably not interested in dealing with land as collateral, not only because they had no information on which plots had been mortgaged previously, or not, but also because the debtors could have resorted to the pledged land to pay interest in kind. The payment of interest in kind would have in turn engendered more transaction costs for these investors, who had turned to the local credit market seeking profitable and safer investments to the detriment of the land market precisely for this reason in the first place. This new group of investors instituted rigidity in credit practices to the detriment of flexibility. They were less prone to negotiate over guarantees and over deadline repayment, as we shall see.

\section{From Flexibility to Standardization: Contracts and Institutions}

Standardization of Contracts. Two critical institutions experienced some collateral effects of credit market dynamism in the second half of the eighteenth century. The institution of the notary and of the local court, which had accompanied creditors and debtors for several centuries, thus underwent major changes. As we have seen, the notary helped rural dwellers write up their contracts and, to a lesser extent, acted as a broker. As the local credit market activities grew, however, the notary was called on more often. He drafted an increasing number of contracts throughout the period. And in turn, he acquired a new status as an expert. His experience made him not only more specialized and reliable regarding legal norms and rules, but he also acquired a greater reputation as an expert within the community (Dermineur 2015). There is a difference between the contracts written at the beginning of the period and those written at the 
end of the period. In the last decade of the Old Regime, contracts had more similar features and tended to be more standardized, following the same framework. There is none of the diversity in agents' input as before (Scott 1999). For instance, the choice of specific pledged land in the deed disappeared almost completely to the benefit of a more general and standardized claim on all the debtor's assets. It seems that the possibility of resorting to land to pay the interest in kind disappeared-most likely because the new group of investors preferred cash rather than crops.

Incidentally, it also seems that the increase in financial exchange had some impact and effect on making the currency system more uniform. At the beginning of the period, at least two different currencies were in use in both seigneuries-livre tournoise and livre bâloise-while at the end of the period only one is left, presumably to simplify exchange. The use of two different currencies could have been beneficial for either the creditor or the debtor; each could have waited for a favorable exchange rate to pay the interest or reclaim the capital. At the end of the eighteenth century, only the livre tournoise was in circulation.

\section{The Rise of the Local Court}

The judicial institution, however, played a major role in the enforcement of loan contracts (Dermineur 2011b). Easily accessible in both seigneuries, the local court represented the coercive arm of the creditors in case of conflicts, especially over repayment deadlines. However, it must be noted that the local civil court's primary purpose was to maintain peace in society, dealing with a wide range of various issues brought up by rural dwellers. In essence, the office of the local judge was carrying out a number of tasks (Dermineur 2011a: 196). In contrast, some judicial institutions, such as the Law Merchant in the case of the fairs of Champagne in the Middle Ages, were created especially to enforce contracts and settle conflicts about merchants, but such institutions remained marginal in the early modern period (Milgrom et al. 2010). In the case of local courts, their prerogatives reached more widely, and the economic aspect was one of the many it encompassed and dealt with. ${ }^{14}$

As the credit market experienced dynamism without precedent in the $1770 \mathrm{~s}$, the local judges (one in each seigneurie) were called on more often as table 7 shows. ${ }^{15}$

In the late seventeenth century, in the seigneurie of Delle, 19 percent of all judicial proceedings concerned debt repayment, while a century later this proportion reached 61.3 percent. The same trend can be observed in the seigneurie of Florimont. ${ }^{16}$ In

14. It is important to note that the local judge, either in Delle or in Florimont, did not apply any specific legal regulations to merchants. There, creditors and debtors followed the customs and practices of the region. No special rule applied to merchants, of whom in any case there were only a handful to extend money.

15. For the seigneurie of Delle ADTB 8B18, 8B19, 8B20, 8B21, 8B31, 8B32, 8B83, 8B84, 8B86, 8B87, 8B88, 8B90, 8B91, 8B92, 8B93, 8B94, 8B95, 8B96, 8B97, 8B98, 8B156, 8B157, 8B158, 8B159, and 8B160. For Florimont, 12B14, 12B15, 12B16, 12B42, 12B43, 12B44, 12B45, 12B46, 12B47, 12B 78 , 12B79, 12B80, 12B81, and 12B82.

16. The registers for the years $1680-85$ are partially missing in Florimont. 
TABLE 7. Default cases at the local court in the seigneurie of Delle and Florimont, 1680-1785

\begin{tabular}{|c|c|c|c|c|c|c|c|c|}
\hline & \multicolumn{2}{|c|}{$1680-85$} & \multicolumn{2}{|c|}{$1700-5$} & \multicolumn{2}{|c|}{$1740-45$} & \multicolumn{2}{|c|}{$1780-85$} \\
\hline & $D$ & $F$ & $D$ & $F$ & $D$ & $F$ & $D$ & $F$ \\
\hline Number of defaults & 72 & N/A & 78 & 69 & 386 & 133 & 805 & 233 \\
\hline Percentage of default in all proceedings & $19 \%$ & N/A & $37 \%$ & $40.8 \%$ & $50.5 \%$ & $57.3 \%$ & $61.3 \%$ & $57 \%$ \\
\hline
\end{tabular}

D: Seigneurie of Delle; F: Seigneurie of Florimont

Vaucouleurs, Hervé Piant also found 39 percent of the causes d'audience related to debt in the late seventeenth century while their number reached 76 percent in the eighteenth century.

As stated in the first section, most of these proceedings in Delle and Florimont were first hearings. Creditors sought the external expertise of the judge to assert the validity of a debt. Either negotiations or foreclosure ensued. More importantly, the social dimension of resorting to the judge in case of a conflict over the repayment of a debt needs to be underlined. This strategy used by creditors served to inform the community of a debtor's inability to keep his promise and therefore contributed to publicizing his loss of social credit, reputation, and honor (Dermineur 2015). In a way, this strategy resembles our own contemporary credit scores.

More importantly, these data show that local courts dealt primarily with debt proceedings to the prejudice of other matters, relegated, therefore, to the background toward the end of the period. New investors sought the enforcement of their contract and/or the renegotiation of the terms of the agreement before a third party, the local judge. The judge consulted in the matter almost exclusively granted creditors contract enforcement and recognition of the debt. Transaction costs consequently did not affect the creditors, as the defendant found guilty had to pay the judicial fees. Zorina Khan argues that third-party collection through the courts was in fact meant to economize on transaction costs. The greater use of the judicial institution was the result of a crisis of confidence and trust, and it is undeniable that the creditors circumvented long negotiations and consensus and reduced transaction costs in claiming repayment before the judge (Kahn 2008: 23).

It seems also that distrust increasingly influenced other creditors. By the last decade of the Old Regime, traditional trust within the community had vanished and the resort to the local court constituted a better strategy to seek repayment. Resorting to the local judge for debt matters became a practice. Nonetheless we might ask to what extent the will of a privileged few redesigned and reshaped the judicial institution and influenced its efficiency and fairness. ${ }^{17}$ 
Evidently, the success of both the notary and the judicial institution must be correlated not only with economic conjunctures, demographic pressure, greater monetization of the economy, and inflation but also with the decline of extrajudicial practices. I contend that the new economic conditions, namely the growing importance of the credit market, modified deeply the nature of the local court and above all its significance for rural dwellers. Embedded in the society, the local court system traditionally responded to the demands of its users and their input shaped the form of the institution. But it can be argued that when a new category of investors emerged, their requests tended to shape in turn the judicial institution, serving their interests first above those of other users, allowing the evolution of the judicial institution into a more specialized one, more efficient in debt conflict resolution, which left aside other litigation-such as assault and battery (Dermineur 2011b and 2015).

\section{Conclusion}

Traditional local credit markets, such as those in early modern France, featured norms of solidarity, fairness, and cooperation and allowed its agents considerable input regarding the terms of their agreement either before contracting and/or afterward. But structural changes in the middle of the eighteenth century, such as an increase in credit activities, drawing on the power and profitability of such exchanges, and the appearance of new investors, affected the social and legal norms and nature of these markets. The gradual and massive resort to external parties-such as the notary and the local court-to handle and manage financial transactions remodeled these institutions into specialized and incontrovertible experts. Not only did their expertise gradually appear indisputable, but they also helped to standardize contracts and legal norms. In our sample, the private credit market shifted from an institution in which input and flexibility prevailed to a more rigid institution in which rules and rigor applied; a framework that still prevails.

Today, debt issues are critical to our modern societies. For example, student debt in the United States has reached a critical ceiling while the level of indebtedness of Chinese households keeps increasing and is now six times larger than in 2007 (Bank for International Settlements 2017). Countries like Greece and Porto Rico, to name just two, are battling to repay their huge public debt. In the United States, peer-to-peer lenders generated 6.6 billion dollars in loans in 2014, up 128 percent from 2013. In Europe, they generated 3.9 billion dollars in 2014, up 144 percent from 2013 (Morgan Stanley 2015). It is likely that debt, either private or public, will constitute a major challenge in the short term.

\section{Archival Sources}

Archives Départementales du Territoire de Belfort, 21J1, 1720 and 1766.

Archives Départementales du Territoire de Belfort, 028 E dépôt GG1-3.

Archives Départementales du Territoire de Belfort, 081 E dépôt GG 1-6. 
Archives Départementales du Territoire de Belfort, 2E4/155, 2E4/156, 2E4/157, 2E4/158, 2E4/159, 2E4/194, 2E4/222, 2E4/223, 2E4/244, 2E4/245, 2E4/246, $2 \mathrm{E} 4 / 257,2 \mathrm{E} 4 / 258,2 \mathrm{E} 4 / 276,2 \mathrm{E} 4 / 279$, 2E4/280, 2E4/287, 2E4/323, 2E4/324, 2E4/325, 2E4/366, 2E4/367, 2E4/368, 2E4/369, 2E4/370, 2E4/371, 2E4/372, 2E4/392, 2E4/409, 2E4/428, 2E4/429, and 2E4/430.).

Archives Départementales du Territoire de Belfort 8B18, 8B19, 8B20, 8B21, 8B31, 8B32, 8B83, 8B84, 8B86, 8B87, 8B88, 8B90, 8B91, 8B92, 8B93, 8B94, 8B95, 8B96, 8B97, 8B98, 8B156, 8B157, 8B158, $8 \mathrm{~B} 159$, and 8B160.

Archives Départementales du Territoire de Belfort, 12B14, 12B15, 12B16, 12B42, 12B43, 12B44, 12B45, 12B46, 12B47, 12B78, 12B79, 12B80, 12B81, and 12B82.

\section{References}

Ago, Renata (1999) "Enforcing agreements: Notaries and courts in early modern Rome." Continuity and Change 14 (2): 191-206.

Alderman, Liz (2015) "Trading meat for tires as bartering economy grows in Greece." New York Times, September 21, http://mobile.nytimes.com/2015/09/22/business/international/ trading-meat-for-tires-as-bartering-economy-grows-in-greece.html?referrer=\&_r=0.

Bank for International Settlements (2017) "National Bureau of Statistics of China." https://www.bis.org/ statistics/totcredit.htm (accessed March 2018).

Baulant, Micheline (1968) "Le prix des grains à Paris de 1431 à 1788." Annales. Histoire, Sciences Sociales 23 (3): 520-40.

Boehler, Jean-Michel (1999) "De la reconstruction agraire à la mise en vente des biens nationaux: Possession de la terre, conjoncture agraire et rapports sociaux dans la plaine d'Alsace (XVII e -XVIII e siècles)." Histoire, Économie et Société 18 (1): 43-62.

Brennan, Thomas (2006) "Peasants and debt in eighteenth-century Champagne." Journal of Interdisciplinary History 37 (2): 175-200.

Briggs, Chris (2009) Credit and Village: Society in Fourteenth-Century England. Oxford: Oxford University Press.

Cheney, C. R. (1972) Notaries Public in England in the Thirteenth and Fourteenth Centuries. Oxford: Oxford University Press.

Claustre, Julie, ed. (2006) La Dette et le Juge. Juridiction Gracieuse et Juridiction Contentieuse du XIIIe au XVe Siècle. Paris: Publications de la Sorbonne.

Coquery, Natacha, and Nicolas Praquin (2008) "Règlement des faillites et pratiques judiciaires." Histoire and Mesure 23 (1): 43-83.

(2013) “Credit, trust and risk," in Safley, T. M. (ed.) The History of Bankruptcy: Economic, Social and Cultural Implications in Early Modern Europe. London: Routledge: 52-71.

Dermineur, Elise M. (2009) "Female peasants, patriarchy, and the credit market in eighteenth-century France." Proceedings of the Western Society for French History 37: 61-84.

- (2011a) "Women in rural society: Peasants, patriarchy and the local economy in Northeast France, $1650-1789 . " P h D$ diss., Purdue University.

(2011b) "The civil judicial system in early modern France." Frühneuzeit-Info 22 (1): 44-53.

(2014a) "Les femmes et le crédit dans les communautés rurales Au 18e siècle." Traverse Revue d'Histoire - Zeitschrift Für Geschichte 2 (2): 53-64.

(2014b) "Single women and the rural credit market in eighteenth-century France." Journal of Social History 48 (1): 175-99.

(2015) "Trust, norms of cooperation, and the rural credit market in eighteenth-century France." Journal of Interdisciplinary History 45 (4): 485-506.

(2016) "Widows' political strategies in traditional communities: Negotiating marital status and authority in eighteenth-century France," in James Daybell and Svante Norrhem (eds.) Gender and Political Culture, 1500-1800. Farnham: Routledge: 123-39. 
(2018) "Rural credit markets in 18th-century France: Contracts, guarantees and land," in Chris Briggs and Jaco Zuijderduijn (eds.) Mortgages in Medieval and Early Modern Europe. London: Palgrave Macmillan: 205-31.

Ferrière, Claude de (1752) La Science Parfaite Des Notaires, Ou Le Parfait Notaire. http://gallica.bnf.fr/ark: /12148/bpt6k1041531v.

(1771) Dictionnaire de droit et de pratique. 2 vols. Paris: Bauche. http://gallica.bnf.fr/ark:/12148/ bpt6k1230375.

Fontaine, Laurence (2008) L’Economie Morale: Pauvreté, Crédit et Confiance dans l'Europe Préindustrielle. Paris: Editions Gallimard.

Graeber, David (2011) Debt: The First 5,000 Years. Brooklyn, NY: Melville House.

(2013) The Democracy Project: A History, a Crisis, a Movement. New York: Spiegel and Grau.

Hoffman, Philip T. (2000) Growth in a Traditional Society: The French Countryside, 1450-1815. Princeton, NJ: Princeton University Press.

Hoffman, Philip, Gilles Postel-Vinay, and Jean-Laurent Rosenthal (1992) "Private credit markets in Paris, 1690-1840.” Journal of Economic History 52 (2): 293-306.

(1994a). "Économie et Politique: Les Marchés du Crédit à Paris, 1750-1840." Annales. Histoire, Sciences Sociales 49 (1): 65-98.

- (1994b) "What do notaries do? Overcoming asymmetric information in financial markets: The case of Paris, 1751.” UCLA Economics Working Paper. Department of Economics, UCLA.

(1999) "Information and economic history: How the credit market in Old Regime Paris forces us to rethink the transition to capitalism.” The American Historical Review 104 (1): 69-94.

(2001a) Des Marchés Sans Prix: Une Economie Politique du Crédit à Paris, 1660-1870. Paris: Editions de 1'Ecole des Hautes Etudes en Sciences Sociales.

(2001b) Priceless Markets: The Political Economy of Credit in Paris, 1660-1870. Chicago: University of Chicago Press.

Hoffman, Philip T., Gilles Postel-Vinay, and Jean-Laurent Rosenthal (2012) "Entry, Information, and Financial Development: A Century of Competition between French Banks and Notaries." Explorations in Economic History 55: 39-57. https://doi.org/10.1016/j.eeh.2014.04.002.

Homer, Sidney (1963) A History of Interest Rates. New Brunswick, NJ: Rutgers University Press.

Isambert, François (1829) Recueil Général des Anciennes Lois Françaises: Depuis l'an 420 jusqu'à la Révolution de 1789. Vol. 16. Paris: Belin-Le-Prieur, Verdiere.

Kadens, Emily (2015) “The medieval law merchant: The tyranny of a construct." Journal of Legal Analysis 7 (2): 251-89.

Khan, B. Zorina (2008) “'Justice of the marketplace': Legal disputes and economic activity on America's northeastern frontier, 1700-1860.” The Journal of Interdisciplinary History 39 (1): 1-35.

Lazzarato, Maurizio (2012) The Making of the Indebted Man: Essay on the Neoliberal Condition. Cambridge, MA: MIT Press.

Les Echos (2015) “Un risqué à onze milliards pour les banques américaines.” July 13, http://www.lesechos. fr/13/07/2015/LesEchos/21978-100-ECH_un-risque-a-11-milliards-pour-les-banques-americaines. htm\#.

Milgrom, Paul R., Douglass C. North, and Barry R. Weingast eds. (2010) "The role of institutions in the revival of trade: The law merchant, private judges, and the Champagne fairs," in Eirik G. Furubotn and Rudolf Richter (eds.) The New Institutional Economics of Markets. Cheltenham, UK: Elgar: 581-603.

Morgan Stanley (2015) “Can P2P lending reinvent lending?,” June 17, https://www.morganstanley.com/ ideas/p2p-marketplace-lending.

Muldrew, Craig (1998) Economy of Obligation: The Culture of Credit and Social Relations in Early Modern England. New York: Palgrave.

Nussdorfer, Laurie (2009) Brokers of Public Trust: Notaries in Early Modern Rome. Baltimore: John Hopkins University Press.

Ogilvie, Sheilagh C. (2007). "'Whatever is, is right?' Economic institutions in pre-industrial Europe.' The Economic History Review 60 (4): 649-84. 
Pfister, Ulrich (1994) "Le Petit Crédit Rural en Suisse aux XVIe-XVIIIe Siècles" Annales. Histoire, Sciences Sociales 49 (6): 1339-57.

Rosenthal, Jean-Laurent (1993) "Credit markets and economic change in southeastern France 1630-1788." Explorations in Economic History 30 (2): 129-57.

(1994) "Rural credit markets and aggregate shocks: The experience of Nuits St. Georges, 17561776." The Journal of Economic History 54 (2): 288-306.

Rozet, Raymond (1966) "Les Traits Originaux du Droit de la Famille Dans le Comté de Belfort à la Fin de l'Ancien Régime." PhD diss., Université de Dijon.

Sarti, Raffaella (2002) Europe at Home: Family and Material Culture, 1500-1800. New Haven, CT: Yale University Press.

Scott, James C. (1977) The Moral Economy of the Peasant: Rebellion and Subsistence in Southeast Asia. New Haven, CT: Yale University Press.

(1999) Seeing Like a State: How Certain Schemes to Improve the Human Condition Have Failed. New Haven, CT: Yale University Press.

Servais, Paul (1994) "De La Rente Au Crédit Hypothécaire En Période de Transition Industrielle. Stratégies Familiales En Région Liégeoise Au XVIIIe Siècle.” Annales. Histoire, Sciences Sociales 49 (6): 1393 1409

Shaw, James (2013) "Market ethics and credit practices in sixteenth-century Tuscany." Renaissance Studies 27 (2): 236-52.

Soldelvila I Temporal Xavier (2014) "Rural courts, notaries and credit in the county of Empúries, 12901348." Continuity and Change 29 (1): 83-114.

Thompson, E. P. (1971) "The moral economy of the English crowd in the eighteenth century." Past and Present 50: 76-136.

Vardi, Liana (1993) The Land and the Loom: Peasants and Profit in Northern France, 1680-1800. Durham, NC: Duke University Press.

Varry, Dominique (1995) "Les Campagnes de la Sudélégation de Belfort au Milieu du XVIIIe Siècle," in Michel Balard (ed.) Paris et Campagnes: Mélanges Offert à Jean Jacquart. Paris: Publications de la Sorbonne: $15-23$.

Waddilove, D. P. (2014) "Mortgages in the early-modern court of Chancery." PhD diss., Cambridge University.

Weber, Max (2008) The Protestant Ethic and the Spirit of Capitalism. Miami: BN Publishing.

YouGov (2015) "Survey report—European results July Greece final," https://d25d2506sfb94s.cloudfront. net/cumulus_uploads/document/tdhcw4tpad/EuropeanResults_July_Greece_final_W.pdf. 